\title{
Подходы к селекции томата для различных типов малообъемной технологии
}

\section{А.С. Ерошевская, Т.А. Терешонкова, Х. Фаравн, В.И. Леунов}

Рассмотрен ряд направлений селекции томата для условий малообъемной технологии. Сформулированы основные этапы селекционной работы с культурой томата для технологии «Фитопирамида» - многоярусной трубной вегетационной установки, предназначенной для гидропонного выращивания растений. Указаны обязательные требования к гибридам томата, предназначенным для выращивания на таком типе вегетационных установок.

Ключевые слова: томат, селекция, устойчивость к болезням, гидропонная технология, многоярусная установка.

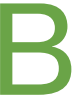
ыращивание овощей в малообъемной культуре на гидропонике - современный, удобный и экономически выгодный способ выращивания растений, получающий все большее распространение как за рубежом, так и в нашей стране. В настоящее время гидропонные технологии применяются в производстве широкого ассортимента с.- х. продукции, включая быстрорастущие листовые, корнеплодные, зеленные и плодовые овощи, в том числе томаты [1]. Сегодня в России насчитывается порядка 2,5 тыс. га зимних высокотехнологичных теплиц, все большее количество фермеров переходит на малообъемный способ выращивания томатов в пленочных теплицах. В ЗАО Агрофирма «Ольдеевская» был проведен сравнительный анализ технологии возделывания томатов закрытого грунта по малообъемной гидропонике (с применением капельного орошения) с традиционной технологией выращивания томата. Главным преимуществом возделывания томата малообъемным гидропонным способом перед традиционным стала урожайность выращиваемых гибридов - по данному показателю малообъемная технология превосходила традиционную почти в 1,5 раза, а рентабельность производства увеличилась в два раза [2].

Для успешного ведения культуры в условиях малообъемной технологии необходимо иметь сорта и гибриды овощных культур, наиболее полно отвечающие требованиям данной технологии выращивания. В настоящее время во всем мире широко ведется се- лекционная работа в этом направлении. Научная работа по этой тематике ведется также и в России, хотя из-за жесткой конкуренции с иностранными семенными фирмами доступный рынок сбыта отечественных семян для малообьемной технологии очень мал.

Селекционеры компании «Гавриш» ведут работу по созданию крупноплодных гибридов томата с комплексом устойчивости к болезням и вредителям для продленного оборота в зимних остекленных теплицах по малообъемной технологии. Ими была создана перспектив- ная модель крупноплодного гибрида томата и проведено конкурсное сортоиспытание новых гибридов собственной селекции. Были выявлены гибриды томата, соответствующие требованиям используемой технологии выращивания [3].

В Федеральном научном центре овощеводства (ФГБНУ ФНЦО) с 2009 года проводится научно-исследовательская работа, цель которой: получение специализированных сортов и гибридов томата, адаптированных к условиям малообъемной технологии - технологии многоярусной узкостеллажной гидропоники (МУГ) [4]. Выполняются пребридинговые исследования, позволяющие изучить наследуемость основных хозяйственно ценных признаков, и целевая гибридизация. К новым формам томата для технологии МУГ селекционеры предъявили следующие требования: детерминантность и низкорослость, высокая продуктивность, раннеспелость и устойчивость к основным за-

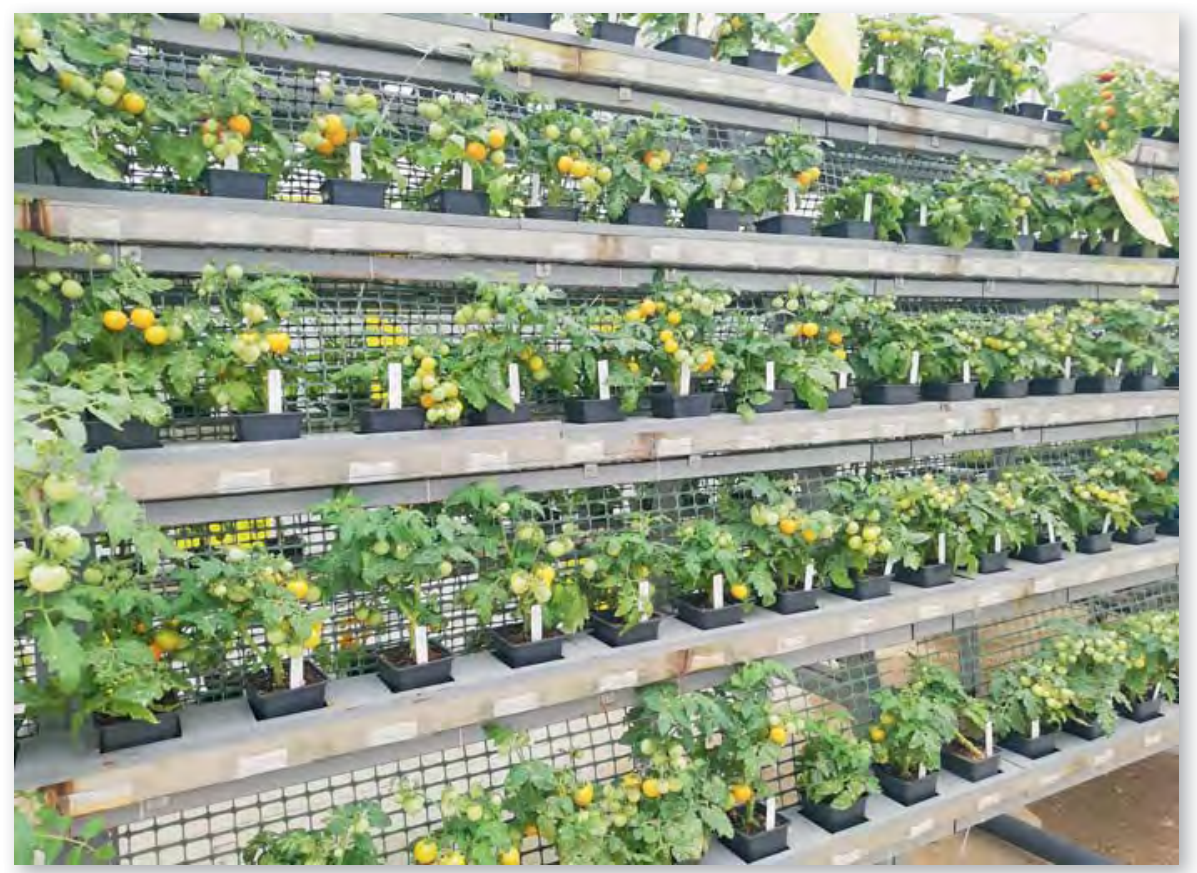

Рис. 1. Карликовые гибриды томата на стеллажной установке МУГ (ФГБНУ ФНЦО) 
болеваниям защищенного грунта [5]. Особое внимание уделяется получению карликовых гибридов, сочетающих низкорослость с указанными ценными признаками [6] (рис. 1).

Учитывая необходимость расширения сортимента томата для малообъемной технологии, как перспективного способа выращивания овощных культур, с целью решения этой проблемы в 2019 году во ВНИИОфилиале ФГБНУ ФНЦО совместно с научно-производственной фирмой «Фитопирамида» была начата селекционная работа в этом направлении.

Для производителей овощей большой интерес представляет многоярусная гидропоника, позволяющая выращивать растения на ограниченной площади и, следовательно, получать высокий экономический эффект. Многоярусные установки имеют разное конструктивное исполнение. Один из вариантов - многоярусная трубная вегетационная установка (МВТУ) «Фитопирамида», разработанная А.И. Селянским и Е.В. Лобашевым. МВТУ предназначена для гидропонного, бессубстратного выращивания растений аэроводным методом (субирригационная аэропоника). Какой-либо субстрат в данной технологии отсутствует [7]. Отсутствие дорогостоящего субстрата, а значит, затрат на мероприятия по его замене и утилизации одно из преимуществ данной технологии [8].

Корневая система растений находится в перфорированных стаканчиках-контейнерах и имеет возможность свободно развиваться в идеальных условиях аэрации [9]. Растения получают сбалансированное минеральное питание из питательного раствора, периодически поступающего к корням (по принципу прилив-отлив). Питательный раствор содержит все микро- и макроэлементы, необходимые растениям в конкретный период роста и развития [8]. Аэроводный способ выращивания исключает возможность накопления избыточного количества солей в прикорневой зоне, позволяет легко проводить контроль за питанием растений и управлять им. Таким образом, технология «Фитопирамида» позволяет создать комфортные для растений условия и исключить влияние факторов окружающей среды, что дает возможность круглогодично выращивать различные культуры, получая высокий урожай при высоком качестве продукции [9]

Вегетационные трубы размещены на нескольких уровнях по высоте, благодаря чему в объеме культивационного сооружения располагается сразу несколько плодоносящих ярусов. Компактность производственных площадей - очередное достоинство МВТУ, ведь инвентарная площадь одной вегетационной установки составляет всего 7,4 м² [7]. Благодаря такой конструкции установки представляется возможным значительно снизить себестоимость продукции и получить максимальную прибыль [9].

Первым этапом селекционного процесса по созданию гибридов для малообъемной культуры типа «Фитопирамида» стало сравнительное испытание сортов и гибридов томата с различной окраской и массой плода (от черри до крупноплодных) селекции ВНИИО - филиала ФНЦО и Агрохолдинга «Поиск» на гидропонных установках и в грунтовой теплице (рис. 2). На основании результатов проведенных исследований были намечены параметры модели гибрида томата для технологии «Фитопирамида».

Создание модели растений томата, приспособленных к условиям МВТУ ключ К достижению поставленной цели. Специфические требования к гибриду томата, адаптированному к условиям выращивания на «Фитопирамиде», обусловлены в первую очередь конструктивным исполнением гидропонной установки - расположением растений в несколько ярусов, а значит, ограничением их по высоте. В связи с этим подбираются супердетерминантные гибриды томата, отличающиеся низкорослостью. Однако на МВТУ возможно выращивать и детерминантные, и индетерминантные гибриды, при условии их формирования до двух-трех кистей с удалением точки роста.

К полезным качествам при возделывании томата в условиях «Фитопирамиды» можно отнести следующие морфологические особенности: укороченные междоузлия и некрупный лист. Ограничение рос-
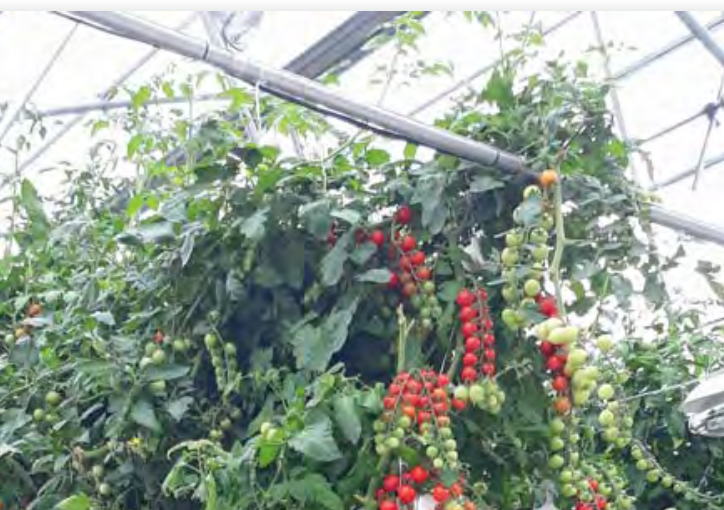
та с групповой устойчивостью к ряду заболеваний.

Первый этап исследований в этом направлении предполагает маркерный отбор исходных форм, основанный на селекции томата по генам, определяющим его устойчивость к основным болезням $\left(\mathrm{I}_{2}, \mathrm{Cf}_{9}, \mathrm{TM}-2^{2}, \mathrm{Mi}-1\right.$, 2, Sw5). Использоdaние молекулярных маркеров позволит достичь высокой точности отбора и ускорить процесс селекции по сравнению с отбором на основании анализа фенотипа [11]. Тем не менее, мы предполагаем контроль устойчивости отобранных по ПЦР-анализу форм на искусственных инфекционных фонах. В дальнейшем в условиях грунтовых пленочных теплиц методом диаллельного скрещивания отобранных родительских линий - доноров устойчивости и других ценных признаков - будут получены гибриды томата, устойчивые к комплексу болезней. Резистентность полученных гибридов к болезням будет определена методами ПЦР-анализа и искусственного заражения сеянцев, выращенных на инфекционном фоне. Последующее испытание новых гибридов на МВТУ «Фитопирамида» с учетом фенологических, биометрических параметров и продуктивности растений поможет выявить гибриды томата, максимально приспособленные к условиям данной технологии выращивания.

\section{Библиографический список}

1.Иванов А.Д. Использование гидропонных техноло гий для выращивания сельскохозяйственных культур // Научное обеспечение агропромышленного комплекса: материалы XII Всероссийской конференции молодых ученых. Краснодар, 2019. С. 227-228.

2.Димитриев В.Л., Косарев Е.В. Возделывание томатов закрытого грунта по малообъемной гидропонике по сравнению с традиционной // Современные проблемы науки и образования. 2015. № 2. С. 747.

3.Кибанова Н.А. Создание крупноплодных гибри дов томата для продленного оборота в зимних остекленных теплицах по малообъемной технологии // Плодоводство и виноградарство Юга России. 2016. № 39. С. $172-180$.

4.Пинчук Е.В., Митрофанова О.А. Получение новых форм томата для многоярусной узкостеллажной гидропоники // Повышение эффективности сельскохозяйственной науки в современных условиях: матери алы международной научно-практической конференции молодых ученых и специалистов. Орел, 2015. С. $125-130$.

5.Пивоваров В.Ф. и др. Создание генетических ресурсов томата для многоярусной узкостеллажной гидропоники // Плодоводство и ягодоводство России. 2012. Т. 34. № 2. C. 106-121.

6.Балашова И.Т., Сирота С.М., Козарь Е.Г. Анализ стратегий селекции томата c d-генами для многоярусной узкостеллажной гидропоники // Овощи России 2015. № 2. С.52-57.

7.Селянский А.И., Лобашев Е.В. Высокопроизводительная, энергоэкономная технология производства томатов. Миф? Реальность! // Овощеводство. 2013. № 2. С. 70-72.

8.Селянский А.И., Лобашев Е.В. Гидропоника на Фитопирамидах // Овощеводство. 2013. № 6. С.
$62-68$.

9.Селянский А.И., Лобашев Е.В. Практическая светокультура на "Фитопирамидах" в светонепроницаемых помещениях // Овощеводство. 2013. № 1. С. 62-65.

10.Скорубская О.И. Разработка экспресс-методов оценки стрессоустойчивости при селекции гибридов F1 томата, устойчивых к вершинной гнили (ВГТ): автореф. дис. ... канд. с.- х. наук. М., 2009. 26 с.

11.Хлесткина Е.К. Молекулярные маркеры в генетических исследованиях и в селекции // Вавиловский журнал генетики и селекции. 2013. Т. 17. № 4/2. С. 1044-1054

\section{Об авторах}

\section{Ерошевская Анастасия}

Сергеевна, аспирант, ФГБНУ ФНЦО, м.н.с., ФГБНУ ВНИИО - филиал ФНЦО. E-mail: eroshnast@yandex.ru

\section{Терешонкова Татьяна}

Аркадьевна, канд. с-х. наук, зав. лабораторией иммунитета и селекции пасленовых культур, ВНИиО - филиал ФГБНУ ФНЦО, селекционер по томату Агрохолдинга «Поиск».

E-mail: tata7707@bk.ru

Фаравн Халед, аспирант кафедры овощеводства, ФГБОУ ВО РГАУ МСХА им. К.А. Тимирязева.

E-mail: farawn@mail.ru

Леунов Владимир Иванович, доктор с. - х. наук, профессор, и. о. декана факультета агрономии и биотехнолОГИи, ФГБОУ ВО РГАУ - МСХА им.

К.А. Тимирязева.

E-mail:vileunov@mail.ru

Approaches to tomato breeding

for different types of small-volume cultivation technology

A.S. Eroshevskaya, postgraduate student of FCVG, junior research fellow of ARRIVG branch of FCVG.

E-mail: eroshnast@yandex.ru

T.A. Tereshonkova, PhD, head of laboratory of immunity and breeding of Solanaceae, ARRIVG - branch of FCVG, tomato breeder of Agricultural holding Poisk. E-mail: tata7707@bk.ru

Khaled Faravn, post-graduate student of

the Department of Vegetable growing of the RSAU - MAA named after K.A. Timiryazev.

E-mail: farawn@mail.ru

V.I. Leunov, DSc., professor, acting dean of agronomy and biotechnology, RASU - MAA named after K.A. Timiryazev.

E-mail:vileunov@mail.ru

Summary. A number of tomato breeding directions for a small-volume technology are considered. The main stages of breeding work with tomatoes for Fitopiramida technology - multi-tier tube vegetation installation for hydroponic plant growing are defined. The mandatory requirements for tomato hybrids intended for cultivation on this type of vegetation plants are specified.

Keywords: tomato, breeding, resistance to diseases, hydroponic technology, multi-tier installation.

\section{Инвестиционный портфель растет}

Инвестиционным комитетом Башкортостана рассмотрены проекты на 170 млрд р.

В 2019 году на республиканском уровне состоялись 28 встреч с инвесторами в формате «Инвестиционных часов». На них рассмотрено 103 проекта общей стоимостью порядка 170 млрд рублей. Итоги работы Инвестиционного комитета региона представил заместитель руководителя Аппарата Правительства РБ Александр Шельдяев, выступая на оперативном совещании, которое провёл Глава Башкортостана Радий Хабиров.

Инвестиционный портфель республики в этом году составит 31 млрд, а в 2020 году - 39 млрд рублей. Наибольшее количество проектов поступило по линии Министерства сельского хозяйства. По одобренным инвестпроектам заключены девять инвестиционных и шесть дополнительных соглашений об увеличении объёмов вложений и корректировке сроков реализации. По ним до 2030 года планируется оказать господдержку на 13,3 млрд рублей. Основными мерами запрашиваемой поддержки, по словам Александра Шельдяева, являются предоставление налоговых льгот, возмещение части затрат на строительство инфраструктуры и покупку оборудования, содействие различных институтов развития. Кроме того, членами Инвестиционного комитета регулярно обсуждаются вопросы создания особой экономической зоны и развития ТОСЭР с приглашением потенциальных резидентов. Итоги этой деятельности будут подробно рассмотрены на одном из заседаний «Инвестчаса». В целом проводимая работа нацелена на реализацию задачи «сентябрьского» Указа Главы республики по доведению годового объёма инвестиций в основной капитал до 500 млрд рублей. Руководитель региона высоко оценил уровень организации встреч с инвесторами.

Источник: www.mcx.ru 